\title{
Determining sedimentary
} material sources in a Brazilian urban lake using $\mathrm{Zn}$ stable isotope compositions of bottom sediments: a preliminary study

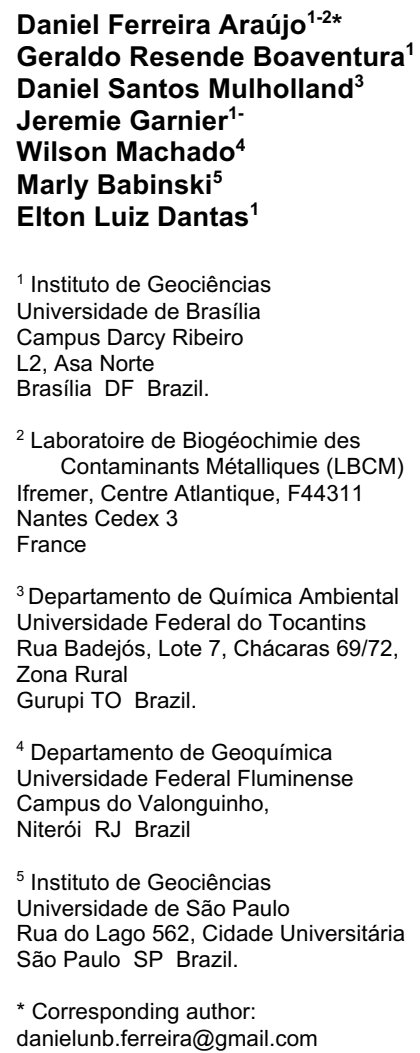

${ }^{3}$ Departamento de Química Ambiental Universidade Federal do Tocantins Rua Badejós, Lote 7, Chácaras 69/72,

* Corresponding author: danielunb.ferreira@gmail.com

\begin{abstract}
RESUMO
As razões dos isótopos de zinco fornecem informações qualitativas e quantitativas sobre as contribuições de diferentes fontes de zinco no ambiente. Apresentam-se os resultados de um estudo preliminar para identificar as principais fontes que controlam as assinaturas de isótopos de $\mathrm{Zn}$ em sedimentos do Lago Paranoá (Brasil), um reservatório urbano de água. As razões isotópicas de $\mathrm{Zn}$ foram medidas por MC-ICP-MS e expressas como notação $\delta^{66 / 64} \mathrm{Zn}$ em relação à solução JMC 3-0749-L. Os sedimentos estudados mostraram valores em um intervalo restrito $(+0,00 \mathrm{a}+0,13 \% ; \mathrm{n}=$ $10)$, semelhante àquele reportado para solos intensamente intemperizados de várias partes do mundo $(-0,4 \mathrm{a}+0,2 \%$ ). O Índice de Geoacumulação (Igeo) também sugere influência baixa ou desprezível de fontes antropogênicas para o Zn. Esta pesquisa fornece uma avaliação das assinaturas de isótopos de Zn em ambientes sedimentares lacustres sob a influência de solos intemperizados.
\end{abstract}

Palavras-chave: isótopos estáveis; MC-ICP-MS; espectrometria de massa; poluição ambiental; contaminação por metais; intemperismo; isótopos de zinco

\section{ABSTRACT}

Zinc isotope ratios provide qualitative and quantitative information about contributions from different $\mathrm{Zn}$ sources in the environment. Here, results of a preliminary study to identify the main sources controlling $\mathrm{Zn}$ isotope signatures are presented for sediments from Lake Paranoá (Brazil), an urban water reservoir. The $\mathrm{Zn}$ isotope ratios were measured by MC-ICP-MS and expressed as $\delta^{66 / 64} \mathrm{Zn}$ notation relative to the JMC 3-0749-L solution. The studied sediments showed a narrow isotopic range $(+0.00$ to $+0.13 \% ; n=10)$ similar to that reported for intensely weathered soils worldwide $(-0.4$ to $+0.2 \%$ ). The Geoaccumulation Index ( $\left.\mathrm{I}_{\mathrm{geo}}\right)$ also suggests low or negligible influence of $\mathrm{Zn}$ from anthropogenic sources. This research provides a baseline assessment of the $\mathrm{Zn}$ isotopic signatures in lacustrine sediments under the influence of weathered soils.

Keywords: stable isotopes; MC-ICP-MS; mass spectrometry; environmental pollution; metal contamination; weathering; zinc isotopes 


\section{INTRODUCTION}

In the past two decades, technological and methodological advances in inorganic mass spectrometry, notably the advent of the multicollector-inductively coupled plasma mass spectrometry (MC-ICP-MS), have enabled researches to determine the variation of $\mathrm{Zn}$ isotope compositions in the environment (MOYNIER et al., 2017). The understanding of the main processes leading to isotopic fractionation (i.e., sorption, redox reactions, biological uptake, evaporation, etc.), their magnitudes and the effect of chemical equilibrium and kinetics fractionation mechanism opened the possibility to use the isotope systematics to obtain important qualitative and quantitative information about sources, transport and behavior of these elements in the environment (WIEDERHOLD, 2015).

Expressed in $\delta^{66 / 64} \mathrm{Zn}$ notation relative to the JMC 3-0749-L standard, $\mathrm{Zn}$ isotopic variations in silicate rocks (including igneous, metamorphic and sedimentary) are small and tend to cluster within a narrow range from +0.20 to $+0.40 \%$ (MOYNIER et al., 2017). Soils present larger ranges of isotope compositions in relation to the parental rock variation from -0.18 to $+0.55 \%$, which can be attributed to the combination of natural abiotic and biological processes in the redistribution of $\mathrm{Zn}$ into different soil horizons during pedogenesis (FEKIACOVA; COMU; PICHAT, 2015). The $\mathrm{Zn}$ isotope compositions of soils are affected by uptake, translocation and distribution of $\mathrm{Zn}$ between the internal compartments of plants (CALDELAS; WEISS, 2016). In turn, man-

\section{EXPERIMENTAL}

\subsection{STUDY AREA AND SAMPLING}

Paranoá Lake $\left(38 \mathrm{~km}^{2}\right.$ surface area, $498 \times 106$ $\mathrm{m}^{3}$ volume, $13 \mathrm{~m}$ and $40 \mathrm{~m}$ mean and maximum depths, respectively) is located in Central Brazil (Fig. 1), east of Brasília city and metropolitan region with a population of about 2.3 million (2.6 million; Distrito Federal), in the Cerradobiome region (Brazilian savanna) at an altitude made materials and byproducts produced in metallurgical and coal plants tend to be isotopically distinct from the Earth crust due to the significant $\mathrm{Zn}$ isotopic fractionation involved in processes such as electrolysis and hightemperature combustion (ARAÚJO et al., 2017a; OCHOA GONZALEZ; WEISS, 2015). In aquatic systems, $\mathrm{Zn}$ isotopes may be fractionated the adsorption on solid surface (such as mineral particles and membranes) or uptake by phytoplankton (GUINOISEAU et al., 2016; JOHN et al., 2007; MOYNIER et al., 2017; SZYNKIEWICZ; BORROK, 2016). Variations of $\delta^{66 / 64} \mathrm{Zn}$ values in particulate matter from a temperate Swiss lake (Lake Greifen) over the seasons were associated to biological isotope fractionation during primary productivity (PEEL; WEISS; SIGG, 2009). In coastal systems, the $\mathrm{Zn}$ isotope signatures of sediments, including surface, core and SPM samples, have been successfully applied to infer source mixing processes involving anthropogenic, marine and terrigenous sources (ARAÚJO et al., 2017a,c; 2018; 2019a,b).

The aim of this work is to measure the $\mathrm{Zn}$ isotope compositions in sediments from the Lake Paranoá, an urban reservoir near the city of Brasília (Brazil) to identify the possible sources, i.e. detrital input from weathered soils or anthropogenic sources. To support the $\mathrm{Zn}$ isotope data interpretation, the GeoAccumulation Index (Igeo) (OCH et al., 2012), mineralogical characterization and source signature data available in the literature were used. between $850 \mathrm{~m}$ and $1300 \mathrm{~m}$ above sea level (STARLING et al., 2002). This lake was created in 1959 to provide electricity to the Brasília capital and as a place for sports, leisure, tourism, landscape composition and dilution of wastewater treatment plants, sewage and storm water drainage (MAR DA COSTA et al., 2016). 


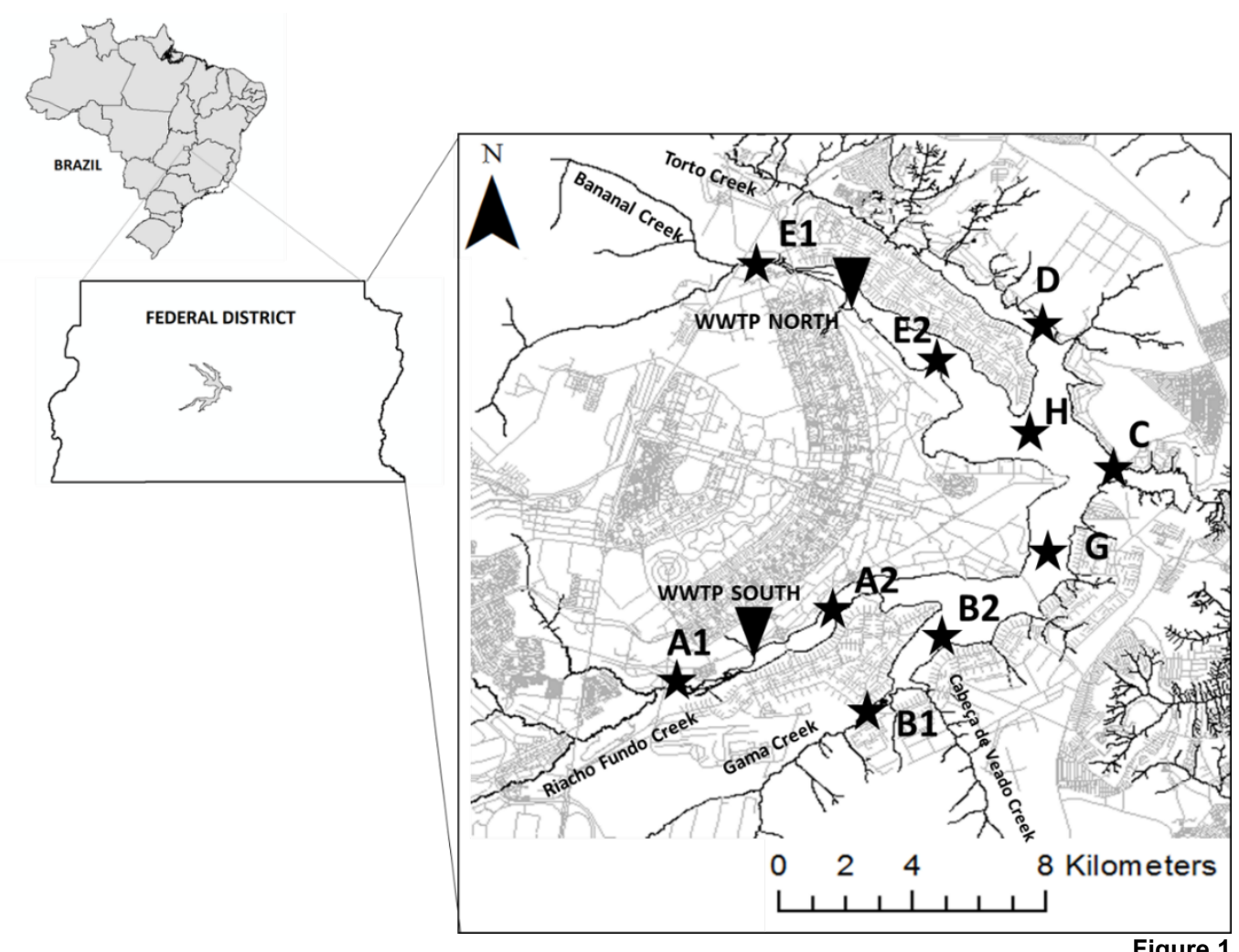

Sampling sites for sediment samples (stars) in the Lake Paranoá and its tributaries. The South and North Waste Water Treatment Plants (WWTP) positions are also indicated.

The regional geology consists of low-grade metamorphic rocks, comprising pelitic, psammitic and carbonate metasediments. Most part of the Paranoá Lake watershed is geologically dominated by the Paranoá Group, which comprise units formed by metasiltites, metarhythmites, quartzites, dolomites and limestones (CAMPOS et al., 2013). More than $85 \%$ of total area of Distrito Federal is covered by extensive lateritic soil and cambissols. They are rich in $\mathrm{Fe}$ and $\mathrm{Al}$ and poor in macro- and micronutrients (GIOIA et al., 2006). The lake has five main tributaries: Riacho Fundo Creek, Gama Creek in its south portion, and Bananal and Torto Creeks in the north. The south region of the lake and the region around its tributaries are densely populated and suffer from rapid processes of pollution (domestic sewage), deforestation and erosion (FRANZ et al., 2014; MAI et al., 2006; MAR DA COSTA et al., 2016; PADOVESI-FONSECA, 2009). In this work, ten sediment samples were taken encompassing the different branches and main creeks that feed the lake (Fig. 1). The samples were collected from the lake using an Ekman grab, while the samples from the creeks were collected using plastic shovels. These sediments were stored in plastic bags and carried to the laboratory, where sediment drying at $40{ }^{\circ} \mathrm{C}$, crushing and sieving at $63 \mu \mathrm{m}$ were carried out. This grain size fraction $(<63 \mu \mathrm{m})$ was used for elemental, mineralogical and isotopic analyses.

\subsection{DETERMINATION OF ZN CONCENTRATIONS AND ISOTOPE COMPOSITIONS BY MC-ICP-MS}

Sediments and reference materials (BCR-2 or BHVO-2) were weighed in Savillex ${ }^{\circledR}$ Teflon beakers with sample masses ranging from 20 to $150 \mathrm{mg}$ and digested using a multiple-step acid attack $\left(21 \mathrm{~mol} \mathrm{~L}^{-1} \mathrm{HF} 14 \mathrm{~mol} \mathrm{~L}^{-1} \mathrm{HNO}_{3}\right.$ and 6 mol $\left.\mathrm{L}^{-1} \mathrm{HCl}\right)$ on a hot plate, as described in Araújo et al. (2017b). Subsequently, the samples were dried again and re-dissolved in $1 \mathrm{ml}$ of 2 mol $\mathrm{L}^{-1} \mathrm{HCl}$ prior to $\mathrm{Zn}$ chromatographic purification. Blanks and the reference materials (BCR-2 or BHVO-2) were included in every sample batch as analytical control in the elemental analysis. Only ultrapure acids (Merck $\left.{ }^{\circledR}\right)$ distilled by sub-boiling in Teflon stills and de-ionized water (Milli-Q, 18.2 M 2 ) were used in the sample preparation. Multi-element 
standard solutions (Merck $\left.{ }^{\circledR}\right)$ were used to produce calibration curves to measure total $\mathrm{Zn}$ concentrations by inductively coupled plasmaoptical emission spectrometer ICP-OES (Spectro Analytical Instrumental $\mathrm{GmbH}$, model Spectroflame FVM03). Accuracy was determined by comparing the measured concentration with the certified value and expressed using percentage relative error (BCR2 and BHVO-2, USGS). The relative errors were within $\pm 10 \%$ in relation to the certified values.

Zinc isotope ratios were measured using the ThermoFinnigan Neptune and Neptune Plus MC-ICP-MS at the Laboratório de Estudos Geodinâmicos e Ambientais at University of Brasília and at the Centro de Pesquisas Geocronológicas (CPGeo) at the São Paulo University, respectively. A detailed description of the methodology is found elsewhere (ARAÚJO et al., 2017b). Briefly, sample aliquots were pre-concentrated to provide about 1-4 $\mu \mathrm{g}$ of $\mathrm{Zn}$ dissolved in $1 \mathrm{~mL}$ of $2 \mathrm{M}$ $\mathrm{HCl}$. The acidified sample was then loaded onto Bio-Rad ${ }^{\circledR}$ plastic columns with about $2 \mathrm{~mL}$ of pre-cleaned 100-200 mesh AG MP-1 resin (Bio$\operatorname{Rad}()$. Matrix elements were eluted by addition of $2 \mathrm{M}$ ultra-pure sub-boiling $\mathrm{HCl}$. After, $\mathrm{Zn}$ was eluted using $0.05 \mathrm{M} \mathrm{HNO}_{3}$. This fraction was evaporated to dryness, doped with $\mathrm{Cu}$ NIST SRM 976 standard and re-dissolved in $3 \% \mathrm{HNO}_{3}$

\subsection{THE GEO-ACCUMULATION INDEX}

The geo-accumulation index ( $\left.\mathrm{I}_{\text {geo }}\right)$ method was used to evaluate the contamination levels of $\mathrm{Zn}$ in sediments using Muller's expression (eq.2) and regional average background available for the Distrito Federal region $\left(\mathrm{Zn}=48.7 \mu \mathrm{g} \mathrm{g}^{-1}\right.$, Arraes Moreira; Boaventura, 2003)

$$
\operatorname{Igeo}(Z n)=\log \left(\frac{Z n \text { sample }}{1.5 * Z n \text { nat.background }}\right) \text { eq. } 2
$$

\subsection{MINERALOGY}

Mineralogical composition was determined by X-ray diffraction (XRD), using a RIGAKU Ultima IV diffractometer (at the University of Brasília, Brazil). The XRD patterns were obtained for powders (0-2 $\mathrm{mm}$ fraction) and air- to reach a concentration between $100-300 \mu \mathrm{g} / \mathrm{L}$ The raw ratios were corrected for instrumental mass fractionation using the exponential law and the certified ratio $(0.4456)$ for $\mathrm{Cu}$ of the NIST SRM 976 standard. The $\mathrm{Zn}$ isotope ratios were reported in $\delta$-notation relative to the Johnson Matthey 3-0749-L (JMC) reference material, as below:

$$
\delta^{66} \mathrm{Zn}(\% 0)=\left(\frac{{ }^{66} \mathrm{Zn} /{ }^{64} \mathrm{Zn}_{\text {sample }}}{{ }^{66} \mathrm{Zn} /{ }^{64} \mathrm{Zn}_{\text {standard }}}-1\right) \text { eq. } 1
$$

The isotopic certified reference material $\mathrm{Zn}$ IRMM $3702(-0.27 \pm 0.06 \%, n=30,2 \sigma)$ and six reference materials (BHVO-2 basalt; BCR-2 basalt; AGV-2 andesite; 2709 San Joaquin soil, 1646a estuarine sediment and 1573a tomato leaves) prepared in different replicates (full protocol including digestion, ion-exchange chromatography and twice isotopic measurements for each replicate) showed good reproducibility $(<0.1 \%, 2 \sigma, 5 \leq n \geq 1)$. All certified materials results are available in Araújo et al. (2017b). Sediment samples of Paranoá Lake were prepared in duplicate with distinct digestion and chromatography, and double measurements were carried out for each one. The average external reproducibility of sediment samples was $\pm 0.08 \%$ o $(2 \sigma, n=40)$ and represents external reproducibility for the entire procedure.

The classification of the $\mathrm{I}_{\text {geo }}$ index according to Muller (1969) is: no pollution ( $\left.\mathrm{I}_{\text {geo }} \leq 0\right)$ ); low pollution $(0<$ Igeo $\leq 1)$; partial median pollution $\left(1<\mathrm{I}_{\text {geo }} \leq 2\right)$; median pollution $\left(2<\mathrm{I}_{\text {geo }} \leq 3\right)$; partial serious pollution $\left(3<\mathrm{I}_{\text {geo }} \leq 4\right)$; serious pollution $\left(4<\mathrm{I}_{\text {geo }} \leq 5\right)$; extreme pollution $\left(\mathrm{I}_{\mathrm{geo}}>5\right)$.

dried, using a Ni-filtered $\mathrm{Cu}-\mathrm{K} \alpha$ radiation and graphite monochromator with an operating voltage of $45 \mathrm{kV}$; beam current of $15 \mathrm{~mA}$; and a scanning speed of $2^{\circ} / \mathrm{min}$ between 2 and $80^{\circ} 2 \theta$. 


\section{RESULTS}

The sediments of Lake Paranoá and tributary creeks presented $\mathrm{Zn}$ isotope compositions within a narrow range $(+0.00$ to $+0.13 \%)$ and $\mathrm{Zn}$ concentration between 21 to $130 \mu \mathrm{g} \mathrm{g}^{-1}$ (Table 1 , Fig. 2A). The highest concentrations were found in samples A2 $\left(102 \mu \mathrm{g} \mathrm{g}^{-1}\right)$ and E2 $\left(131 \mu \mathrm{g} \mathrm{g}^{-1}\right)$, both collected at downstream points from the south and north Waste Water Treatment Plants (WWTPs), respectively (Fig. 1). The sediments collected in the creeks (A1, B1, E1) showed Zn concentrations lower than those in sediments from the lake. This is explained by their coarser grain size in these environments, in contrast with the finer particles of lake sediments.

Sediment samples A2, B2 and E2 are classified as low contaminated (Igeo values between 0 and 1), while all other samples are classified as uncontaminated (Igeo values $\leq 0$ ). The $\delta^{66} \mathrm{Zn}$ values and $\mathrm{Zn}$ concentrations were not correlated $\left(\mathrm{R}^{2}=0.07, p<0.05\right)$ and the scatter plot of these variables did not appoint any tendency of mixing source processes or sample grouping. Despite the gradient of $\mathrm{Zn}$ concentrations, analysis of variance (ANOVA) indicated no significant statistical difference on $\delta^{66} \mathrm{Zn}$ values of sediments $(p>0.05)$.

The X-ray diffraction (XRD) of samples showed that quartz, gibbsite, kaolinite and illite are dominant minerals in the samples, while vermiculite, rutile, muscovite, goethite, hematite and anatase occur as accessory minerals.

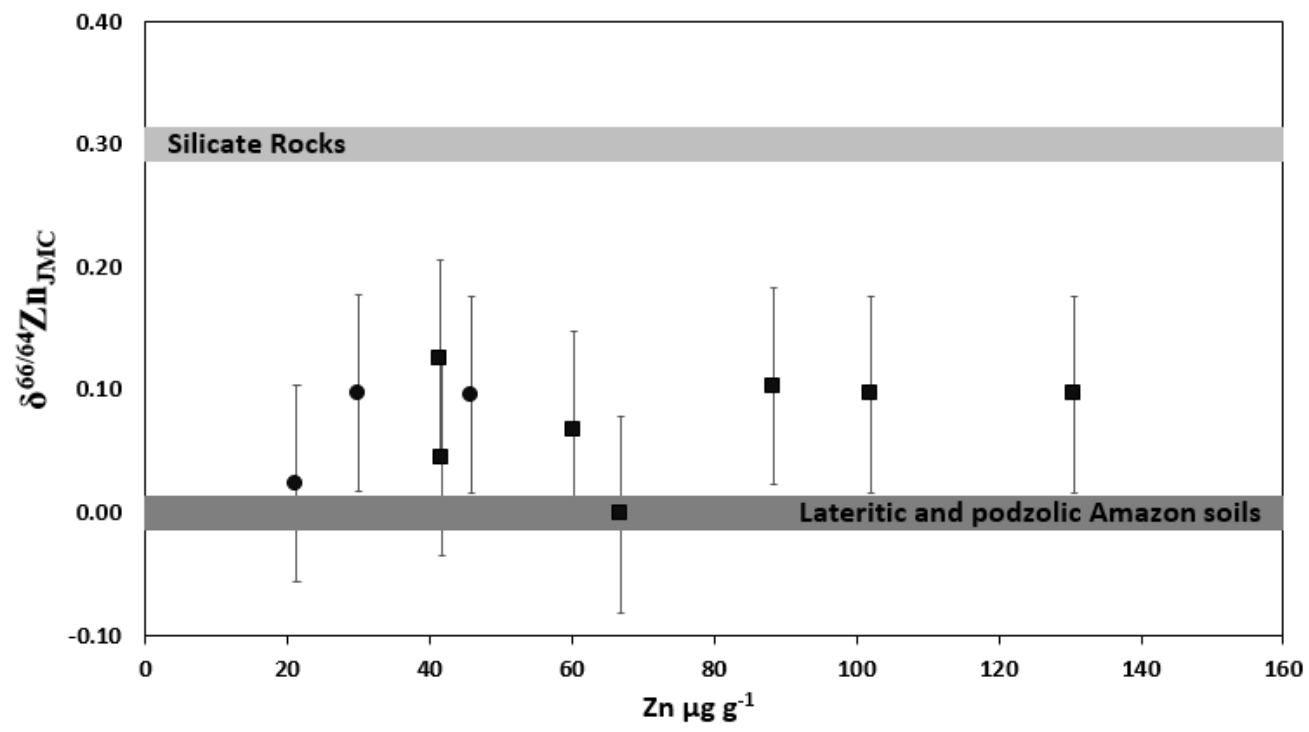

Figure 2 Scatter plot of $\delta^{66 / 64} \mathrm{Zn}$ values versus $\mathrm{Zn}$ concentrations for sediments from the Paranoá Lake. Circle dots represent sediment collected in the creeks; square dots represent sediments collected in the branches and in the central area of the Paranoá Lake.

\section{DISCUSSION}

\subsection{MAIN CONTROLLING FACTOR OF ZINC ISOTOPE COMPOSITIONS IN SEDIMENTS OF PARANOÁ LAKE}

The Central Plateau of Brazil contains soils formed over long periods of pedogenic weathering under acid $\mathrm{pH}$. In general, these soils tend to be leached and depleted in divalent trace element such as Zn (MARQUES et al., 2004) The main minerals in these soils are 1) primary resistant minerals (i.e., quartz), and 2) iron and aluminum-rich weathering products (i.e., goethite, hematite, and kaolinite)
(MARQUES et al., 2004). The mineralogical assemblies of Lake Paranoá sediments, composed mostly by clay minerals and $\mathrm{Al}$ and $\mathrm{Fe}$ oxyhydroxides, are consistent with highly weathered materials derived from these soils.

Zinc isotope ratios of Paranoá Lake sediments are isotopically lighter than the continental crust, whith an isotope average estimated about $+0.28 \pm 0.08 \%$ (Fig. 2). In turn, 
the studied samples are similar to Zinc isotope compositions of lateritic $(-0.07 \pm 0.1 \%, 1 \sigma, \mathrm{n}=3)$ and podzolic soils $(+0.04 \pm 0.1 \%, 1 \sigma, \mathrm{n}=3)$ from the Rio Negro (Amazon) (GUINOISEAU et al., 2017). The $\mathrm{Zn}$ isotopic variability in soils have been associated to the pedogenesis processes transformation of the saprolite horizon into a ferruginous and clay-rich horizons (VIERS et $a l .$, 2007a). The mechanisms of this process have been attributed to the equilibrium fractionation between aqueous organic species that are removed from the soil versus sorption on clay minerals and (Fe-Mn)-oxyhydroxides. In this processes the $\mathrm{Zn}$ present in solution is slightly enriched in heavy isotopes while the $\mathrm{Zn}$ reminiscent in the residual solid phase is slightly enriched in light isotopes (GUINOISEAU et al., 2017; MOYNIER et al., 2017; VIERS et al., 2007b). Amazon soils, under an extreme weathering regime, showed lighter $\mathrm{Zn}$ isotope composition which were associated to the enrichment of light $\mathrm{Zn}$ isotope in residual crystalline phases (such as kaolinite in laterite) (GUINOISEAU et al., 2017, 2018). These soils contrast with soils developed on granitoid (Scotland) and basaltic (Hawaiian Islands) rock substrates, or in Siberian regions, where small isotope fractionation of $\mathrm{Zn}$ was observed in relation to silicatic rocks (MOYNIER et al.,
2017; VANCE et al., 2016; VIERS et al., 2015). The $\mathrm{Zn}$ isotopic variability in soils remains poorly understood but weathering regime and drainage patterns (that may affect Fe-Mn oxydroxides formation and dissolution) seem to be the major controlling factors (VANCE et al., 2016). Thus, it is plausible that the wide occurrence of kaolinite and $\mathrm{Mn} / \mathrm{Fe}$ oxyhydroxides in the sediments of Paranoá Lake, originated mostly from weathered soils, reflecting the light isotopic composition of $\mathrm{Zn}$ in these samples.

In addition to the natural soil source influence on the $\mathrm{Zn}$ isotope compositions of sediment samples, potential anthropogenic $\mathrm{Zn}$ sources could affect their isotopic signatures. Recent studies have demonstrated the influence of diffuse (urban traffic load and domestic untreated) and punctual anthropogenic sources (Wastewater Treatment Plants (WWTPs) on trace elements and nutrients budgets (FRANZ et al., 2014; GIOIA et al., 2006; MAR DA COSTA et al., 2016). However, the low $\mathrm{I}_{\mathrm{geo}}$ values suggest low or negligible anthropogenic $\mathrm{Zn}$ source influence on $\mathrm{Zn}$ isotope compositions of lake sediments. Moreover, the plot of $\delta^{66 / 64} \mathrm{Zn}$ values versus $\mathrm{Zn}$ concentrations does not show evidence of any mixing source processes.

Table 1. Zinc isotope compositions, Zinc concentrations and Igeo values of sediment samples in the Lake Paranoá.

\begin{tabular}{|c|c|c|c|c|}
\hline Samples & $* \delta^{66 / 64} \mathrm{Zn}$ JMC & $2 \sigma$ & $\mathrm{Zn} \mu \mathrm{g} \mathrm{g}^{-1}$ & Igeo \\
\hline A1 & 0.02 & 0.06 & 21 & -1.8 \\
\hline $\mathbf{A 2}$ & 0.10 & 0.07 & 102 & 0.5 \\
\hline B1 & 0.10 & 0.11 & 46 & -0.7 \\
\hline B2 & 0.10 & 0.07 & 88 & 0.3 \\
\hline $\mathbf{C}$ & 0.00 & 0.06 & 67 & -0.1 \\
\hline D & 0.04 & 0.13 & 42 & -0.8 \\
\hline E1 & 0.10 & 0.11 & 30 & 1.3 \\
\hline E2 & 0.10 & 0.06 & 131 & 0.8 \\
\hline G & 0.07 & 0.07 & 60 & -0.3 \\
\hline H & 0.13 & 0.11 & 42 & -0.8 \\
\hline Average & & 0.08 & & \\
\hline
\end{tabular}

\section{CONCLUSIONS}

Zinc isotopic signatures in sediments of the Paranoá Lake occurred within a narrow range $(+0.00$ to $+0.13 \%)$. The homogenous $\mathrm{Zn}$ isotope compositions likely reflects dominant input of intensely weathered soils typically found in the region (composed mostly of lateritic soils), which probably underwent light $\mathrm{Zn}$ isotope enrichment during pedogenesis. The low $\mathrm{I}_{\text {geo }}$ values suggest low influence of anthropogenic $\mathrm{Zn}$ sources. Therefore, this research provides a natural baseline assessment of the $\mathrm{Zn}$ isotopes signatures in sediments of lacustrine environments under the influence of weathered soils. 


\section{ACKNOWLEDGEMENTS}

This work was financially supported by CNPQ (D.F. Araújo Ph.D. grant, number: 161944/2012-4 and postdoctoral grant number: 150310/2017-0). The authors thank all the technical staff of the Institute of Geociences of Brasília especially, Erico N. P. Zacchi, Myller

\section{REFERENCES}

ARAÚJO, D. F.; BOAVENTURA, G. R.; MACHADO, W.; VIERS, J.; WEISS, D.; PATCHINEELAM, S. R., RUIZ, I., RODRIGUES, A. P. C.; BABINSKI, M.; DANTAS, E. (2017a). Tracing of anthropogenic zinc sources in coastal environments using stable isotope composition. Chemical Geology, 449:226-235.

https://doi.org/10.1016/j.chemgeo.2016.12.004

ARAUJO, D. F.; BOAVENTURA, G. R.; VIERS, J.; MULHOLLAND, D. S.; WEISS, D.; ARAÚJO, D.; LIMA, B.; RUIZ, I.; MACHADO, W.; BABINSKI, M.; DANTAS, E. (2017b). Ion exchange chromatography and mass bias correction for accurate and precise $\mathrm{Zn}$ isotope ratio measurements in environmental reference materials by MC-ICP-MS. Journal of the Brazilian Chemical Society, 28(2):225-235. https://doi.org/10.5935/0103-5053.20160167

ARAUJO, D. F.; MACHADO, W.; WEISS, D.; MULHOLLAND, D. S.; GARNIER, J.; SOUTOOLIVEIRA, C. E.; BABINSKI, M. (2018). Zinc isotopes as tracers of anthropogenic sources and biogeochemical processes in contaminated mangroves. Applied Geochemistry. https://doi.org/10.1016/j.apgeochem.2018.05.008

ARAÚJO, D. F.; PONZEVERA, E.; BRIANT, N.; KNOERY, J.; BRUZAC, S.; SIREAU, T.; BRACH-PAPA, C. (2019a). Copper, zinc and lead isotope signatures of sediments from a mediterranean coastal bay impacted by naval activities and urban sources. Applied Geochemistry.

https://doi.org/10.1016/j.apgeochem.2019.104440

ARAÚJO, D. F.; PONZEVERA, E.; BRIANT, N.; KNOERY, J.; SIREAU, T.; MOJTAHID, M.; METZGER, E.; BRACH-PAPA, C. (2019b). Assessment of the metal contamination evolution in the Loire estuary using $\mathrm{Cu}$ and $\mathrm{Zn}$ stable isotopes and geochemical data in sediments. Marine Pollution Bulletin. https://doi.org/10.1016/j.marpolbul.2019.04.034

CALDELAS, C.; WEISS, D. J. (2016). Zinc Homeostasis and isotopic fractionation in plants: A review. Plant and Soil. https://doi.org/10.1007/s11104-016-3146-0
Tonhá Fernando Cavalcante and B. Alcantâra for their collaboration with this work. A special thanks to Professor Dominik Weiss for his cooperation and support in the last years. The authors also thank Timothy Mulholland for his help in reviewing the manuscript.

CAMPOS, J. E. G.; DARDENNE, M. A.; FREITASSILVA, F. H.; MARTINS-FERREIRA, M. A. C. (2013). Geologia do Grupo Paranoá na porção externa da Faixa Brasília. Brazilian Journal of Geology, 43(3):461-476

https://doi.org/10.5327/Z231748892013000300004

FEKIACOVA, Z.; CORNU, S.; PICHAT, S. (2015). Tracing contamination sources in soils with $\mathrm{Cu}$ and $\mathrm{Zn}$ isotopic ratios. Science of the Total Environment.

https://doi.org/10.1016/j.scitotenv.2015.02.046

FRANZ, C.; MAKESCHIN, F.; WEIß, H.; LORZ, C. (2014). Sediments in urban river basins: Identification of sediment sources within the Lago Paranoá catchment, Brasilia DF, Brazil-Using the fingerprint approach. Science of the Total Environment, 466-467:513-523

https://doi.org/10.1016/j.scitotenv.2013.07.056

GIOIA, S. M. C. L.; PIMENTEL, M. M.; TESSLER, M.; DANTAS, E. L.; CAMPOS, J. E. G.; GUIMARÃES, E. M.; MARUOKA, M. T. S.; NASCIMENTO, E. L. C. (2006). Sources of anthropogenic lead in sediments from an artificial lake in Brasília-central Brazil. Science of the Total Environment, 356(1-3):125-142

https://doi.org/10.1016/j.scitotenv.2005.02.041

GUINOISEAU, D.; BOUCHEZ, J.; GELABERT, A.; LOUVAT, P.; MOREIRA-TURCQ, P.; FILIZOLA, N.; BENEDETTI, M. F. (2018). Fate of particulate copper and zinc isotopes at the Solimões-Negro river confluence, Amazon Basin, Brazil. Chemical Geology https://doi.org/10.1016/j.chemgeo.2018.05.004

GUINOISEAU, D.; GÉLABERT, A.; ALLARD, T.; LOUVAT, P.; MOREIRA-TURCQ, P.; BENEDETTI, M. F. (2017). Zinc and copper behaviour at the soil-river interface: New insights by $\mathrm{Zn}$ and $\mathrm{Cu}$ isotopes in the organic-rich Rio Negro basin. Geochimica et Cosmochimica Acta. https://doi.org/10.1016/j.gca.2017.06.030

GUINOISEAU, D.; GÉLABERT, A.; MOUREAU, J.; LOUVAT, P.; BENEDETTI, M. F. (2016). Zn Isotope Fractionation during Sorption onto Kaolinite. Environmental Science and 
Technology.

https://doi.org/10.1021/acs.est.5b05347

JOHN, S. G.; GEIS, R. W.; SAITO, M. A.; BOYLE, E. A. (2007). Zinc isotope fractionation during high-affinity and low-affinity zinc transport by the marine diatom Thalassiosira oceanica. Limnology and Oceanography. https://doi.org/10.4319/1o.2007.52.6.2710

MAI, P. D.; BOAVENTURA, G. R.; PIRES, A C. B. (2006). DISTRIBUIÇÃO ESPACIAL DE ELEMENTOS-TRAÇO EM Sedimentos do Lago Paranoá-FD, Brasil. Geochimica, 20(2):158-174.

MAR DA COSTA, N. Y.; BOAVENTURA, G. R.; MULHOLLAND, D. S.; ARAÚJO, D. F.; MOREIRA, R. C. A.; FAIAL, K. C. F.; BOMFIM, E. DE O. (2016). Biogeochemical mechanisms controlling trophic state and micropollutant concentrations in a tropical artificial lake. Environmental Earth Sciences. https://doi.org/10.1007/s12665-016-5629-y

MARQUES, J. J.; SCHULZE, D. G.; CURI, N.; MERTZMAN, S. A. (2004). Trace element geochemistry in Brazilian Cerrado soils. Geoderma, 121(1-2):31-43

https://doi.org/10.1016/j.geoderma.2003.10.003

MOREIRA, R. C.; BOAVENTURA, G. R. (2003). Referência geoquímica regional para a interpretaç ão das concentrações de elementos químicos nos sedimentos da bacia do Lago Paranoá-DF. Quimica Nova, 26(6), 812-820 https://doi.org/10.1590/S0100-40422003000600006

MOYNIER, F.; VANCE, D.; FUJII, T.; SAVAGE, P. (2017). The Isotope Geochemistry of Zinc and Copper. Reviews in Mineralogy and Geochemistry, 82(1):543-600 https://doi.org/10.2138/rmg.2017.82.13

OCH, L. M.; MÜLLER, B.; VOEGELIN, A.; ULRICH, A.; GÖTTLICHER, J.; STEINIGER, R.; MANGOLD, S.; VOLOGINA, E. G.; STURM, M. (2012). New insights into the formation and burial of $\mathrm{Fe} / \mathrm{Mn}$ accumulations in Lake Baikal sediments. Chemical Geology, 330331:244-259.

https://doi.org/10.1016/j.chemgeo.2012.09.011

OCHOA GONZALEZ, R.; WEISS, D. (2015). Zinc Isotope Variability in Three Coal-Fired Power Plants: A Predictive Model for Determining Isotopic Fractionation during Combustion. Environmental Science and Technology. https://doi.org/10.1021/acs.est.5b02402

PADOVESI-FONSECA, C. (2009). Limnological features after a flushing event in Paranoá
Reservoir, central Brazil. Acta Limnol ..., 21(3), 277-285.

PEEL, K., WEISS, D.; SIGG, L. (2009). Zinc isotope composition of settling particles as a proxy for biogeochemical processes in lakes: Insights from the eutrophic Lake Greifen, Switzerland. Limnology and Oceanography. https://doi.org/10.4319/lo.2009.54.5.1699

STARLING, F.; LAZZARO, X.; CAVALCANTI, C.; MOREIRA, R. (2002). Contribution of omnivorous tilapia to eutrophication of a shallow tropical reservoir: Evidence from a fish kill. Freshwater Biology, 47(12):2443-2452 https://doi.org/10.1046/j.1365-2427.2002.01013.x

SZYNKIEWICZ, A.; BORROK, D. M. (2016). Isotope variations of dissolved $\mathrm{Zn}$ in the Rio Grande watershed, USA: The role of adsorption on $\mathrm{Zn}$ isotope composition. Earth and Planetary Science Letters. https://doi.org/10.1016/j.eps1.2015.10.050

VANCE, D.; MATTHEWS, A.; KEECH, A.; ARCHER, C.; HUDSON, G.; PETT-RIDGE, J.; CHADWICK, O. A. (2016). The behaviour of $\mathrm{Cu}$ and $\mathrm{Zn}$ isotopes during soil development: Controls on the dissolved load of rivers. Chemical Geology. https://doi.org/10.1016/j.chemgeo.2016.06.002

VIERS, J.; OLIVA, P.; NONELL, A.; GÉLABERT, A.; SONKE, J. E.; FREYDIER, R.; GAINVILLE, R.; DUPRÉ, B. (2007a). Evidence of $\mathrm{Zn}$ isotopic fractionation in a soil-plant system of a pristine tropical watershed (Nsimi, Cameroon). Chemical Geology. https://doi.org/10.1016/j.chemgeo.2007.01.005

VIERS, J.;; OLIVA, P.; NONELL, A.; GÉLABERT, A.; SONKE, J. E.; FREYDIER, R.; GAINVILLE, R.; DUPRÉ, B. (2007b). Evidence of $\mathrm{Zn}$ isotopic fractionation in a soil-plant system of a pristine tropical watershed (Nsimi, Cameroon). Chemical Geology, 239(1-2):124-137

https://doi.org/10.1016/j.chemgeo.2007.01.005

VIERS, J.; PROKUSHKIN, A. S.; POKROVSKY, O. S.; KIRDYANOV, A. V.; ZOUITEN, C.; CHMELEFF, J.; MEHEUT, M.; CHABAUX, F.; OLIVA, P.; DUPRÉ, B. (2015). Zn isotope fractionation in a pristine larch forest on permafrost-dominated soils in Central Siberia. Geochemical Transactions. https://doi.org/10.1186/s12932-015-0018-0

WIEDERHOLD, J. G. (2015). Metal stable isotope signatures as tracers in environmental geochemistry. In Environmental Science and Technology (Vol. 49, Issue 5, pp. 2606-2624). https://doi.org/10.1021/es504683e 